\title{
KEGIATAN TAHFIDZUL QURAN PADA MASA PANDEMI COVID-19 DI MI TARBIYATUL ATHFAL KARANG CEMPAKA
}

\author{
Fatimatus Zahrah \\ IAIN Madura \\ fatimahazzahrah805@iainmadura.ac.id
}

\begin{abstract}
Abstrak
Saat pandemi covid-19 merubah segala tatanan aspek kehidupan, dunia pendidikan pun mendapat imbasnya. Pembelajaran tidak lagi diperkenankan lagi secara tatap muka. Dengan alasan menghindari penyebaran covid-19. Pembelajaran jarak jauh diterapkan di setiap tingkat pendidikan. Begitu juga kegiatan Tahfidzul Quran di MI Tarbiyatul Athfal, kegiatan tersebut tetap dilaksanakan saat pandemi melalui daring dan luring. Hal ini membuat guru, siswa, dan orang tua harus siap mengikuti kebijakan tersebut. Penelitian ini bertujuan untuk mendeskripsikan bagaimana pelaksanaaan kegiatan tahfidzul quran di MI Tarbiyatul Athfal saat pandemi. Metode penelitian yang digunakan adalah kualitatif dengan pendekatan studi kasus. Data yang digunakan adalah data primer dan sekunder. Data tersebut dikumpulkan melalui tiga cara, yaitu wawancara, observasi, dan dokumentasi. Hasil penelitian ini menunjukkan bahwa kegiatan tahfidzul quran di MI Tarbiyatul Athfal dilakukan secara daring dengan menggunakan aplikasi whatsapp dengan metode sima'i melalui video call. Terdapat kekurangan saat daring, yaitu bacaan siswa kurang fasih dari segi tajwid maupun makhorijul hurufnya. Kemudian kegiatan tahfidz ini dilanjutkan secara luring untuk menyempurnakan kekurangan saat pelaksanaan secara daring. Kesimpulan dari penelitian ini adalah kegaiatan tahfidz secara luring lebih efektif daripada secara daring, hal ini ditunjukkkan dari capaian hafalan beserta kualitas hafalan siswa.
\end{abstract}

\section{Kata Kunci: Kegiatan, Tahfidzul Quran, Pandemi, Covid-19}

\begin{abstract}
When the Covid-19 pandemic changed all aspects of life. Educational life also gets the impact. Learning is no longer allowed face-to-face. With the excuse of avoiding the spread of covid-19. Distance learning is applied at every level of education. Likewise, the activities of Tahfidzul Quran at MI Tarbiyatul Athfal, these activities are still carried out during the pandemic by online and offline. This makes teachers, students, and parents ready to follow these policies. This study aims to describe how the implementation of tahfidzul quran activities at MI Tarbiyatul Athfal during a pandemic. The research method used is qualitative with a case study approach. The data used are primary and secondary data. The data was collected in three ways, namely interviews, observation and documentation. The results of this study indicate that the activities of tahfidzul quran at MI Tarbiyatul Athfal are carried out online using the WhatsApp application with the sima'i method via video call. There are deficiencies when online, namely the students' reading is not fluent in terms of recitation and literacy. Then this tahfidz activity
\end{abstract}


was continued offline to make up for the shortcomings when implementing it online. The conclusion of this study is that offline tahfidz activities are more effective than online, this is shown from the memorization performance and the quality of students' memorization.

Keywords: Kegiatan, Tahfidzul Quran, Pandemi, Covid-19

\section{PENDAHULUAN}

Setahun ini warga dunia digemparkan oleh penyebaran virus mematikan yaitu virus Corona atau yang biasa dikenal dengan covid-19. Virus tersebut mulai menyebar akhir tahun 2019 yang diawali di kota Wuhan, provinsi Hubei Tiongkok. Dan penyebaran pertama kali di Indonesia pada awal maret 2020 yang berasal dari penularan 2 orang asal jepang. ${ }^{1}$

Kegiatan tahfidz quran tentu sudah tidak asing bagi kita. Kata tahfidz berasal dari lafadz حفظ-يحفظ_حفظا yang artinya adalah selalu ingat dan sedikit lupa ${ }^{2}$. Dengan kata lain selalu ingat berarti hafal. Sedangkan abdul aziz abdul rauf mendefinisikan tahfidz dengan kegiatan mengulang sesuatu dengan metode membaca atau mendengar ${ }^{3}$. Jadi, definisi tahfidzul quran merupakan rangkaian kegiatan yang didalamnya terdapat proses penjagaan dan pemeliharaan kemurnian Alquran yang diturunkan kepada Rasulullah SAW untuk menghindari adanya perubahan dan pemalsuan alquran.

Saat ini hampir setiap sekolah tingkat dasar melaksanakan program tahfidz. Semangat sekolah untuk mencetak lulusannya menjadi penghafal Al-Quran sangat tinggi. Hal ini tampak pada persaingan sekolah yang rata-rata melaksanakan program tahfidz dengan target hafalan yang berbeda-beda, mulai yang hanya juz 30, 2 juz bahkan lebih dari 5 juz.

Pandemi kali ini menyebabkan semua aspek kehidupan terganggu. Efek yang sangat besar dan menyakitkan dirasakan berbagai pihak. Tidak hanya pada bidang ekonomi, politik, social dan tentunya juga di aspek pendidikan. Physical Distancing pun dilakukan yang berujung kepada kebijakan Work From Home bagi pekerja, dan Learning From Home bagi pelajar. Dan di sector pendidikan sendiri kemendikbud mengeluarkan surat edaran no.03 tahun 2020 tentang pencegahan penyebaran covid-19.

Dengan terpaksa pemerintah mengambil jalan pelaksanaan pembelajaran jarak jauh. Pemerintah melarang keras bahkan akan memberikan sanksi bagi sekolah yang tetap memaksa melakukan pembelajaran tatap muka. Pelaku dunia pendidikan pun bingung dengan diterapkannya kebijakan baru tersebut. Banyak sekolah libur, bahkan pesantren

\footnotetext{
${ }^{1}$ https://www.kompas.com/sains/read/2020/05/11/130600623/diumumkan-awal-maret-ahli--viruscorona-masuk-indonesia-dari-januari

${ }^{2}$ Mahmud Yunus, Kamus Arab Indonesia, (Jakarta, Mahmud Yunus Dzurriyah, 2013)

${ }^{3}$ Abdul Aziz, Kiat Sukses Menjadi Hafidz Quran Da'iyah, (Bandung, PT Syamil Cipta Media,2004)cet 4 hal 49
} 
memulangkan santrinya untuk menghindari penyebaran covid-19 ini. Usaha yang dilakukan pemerintah ini tidak lain untuk memutus mata rantai penyebaran covid-19 di Indonesia.

Pembelajaran jarak jauh merupakan kegiatan belajar mengajar yang penyampaian bahan ajarnya memakai akses teknologi internet. Pembelajaran yang biasanya dilakukan di kelas-kelas digantikan dengna kelas virtual yang memang harus menggunakan akses internet. Demikian juga sekolah yang melaksanakan program tahfidzul quran terpaksa menghentikan pembelajaran tatap muka dan beralih melakukan kegiatan tahfidz dari rumah melalui metode daring. Karena pada kenyataannya menanamkan cinta alquran dan mencetak generasi qurani tidak boleh serta merta terhenti akibat penyebaran covid-19 ini.

Dengan kondisi demikian maka program tahfidz yang biasanya menggunakan metode sima'i, talaqqi, tikrar, dan sebagainya tidak lagi bisa digunakan secara tatap muka. Di berbagai lembaga, madrasah harus tetap berjalan begitupun dengan program tahfidznya. Ditemukan dalam penelitian terdahulu, seperti yang dipaparkan oleh Widiani Hidayati dalam jurnal Pembelajaran Tahfidzul Quran di Pesantren pada Masa Pandemi Covid-19 bahwa program tahfidz yang dilaksanakan di Pesantren Tahfidz Daarul Quran Takhassus II Cikarang dengan blended learning yaitu dengan luring dan daring dengan tetap memakai metodo sorogan dan sima'inya. Hanya saja perbedaannya pada saat daring dilakukan melalui wattsap .melalui whattsap. ${ }^{4}$

Begitu juga yang disampaikan dalam artikel Rahmat Rifai Lubis, Muhammad Ali Hanafiah, Dewi Sartika, Anggi Arrumaisyah Hasibuan, dan Kamal Hadi Nawawi yang berjudul Tahfidz Online (Studi Menghafal Al-Quan di MIS Ubudiyah Medan) pada Jurnal Pendidikan Islam Vol.09 Nomor 02 tahun 2019. Pada artikel tersebut menyebutkan bahwa Di MIS Ubudiyah Medan melakukan Hifdzul Quran melalui media whattsap dengan voice call, video call recording, atau video call ${ }^{5}$.

Lain halnya dengan yang terjadi di salah satu SMP di daerah Bandar Lampung yang diteliti oleh Maria Ulfa dalam penelitiannya yang berjudul Implementasi Pembelajaran Tahfidzul Quran Pada Masa Pandemi Covid-19 di SMP Quran Darul Fattah Bandar Lampung bahwa pelaksanaan pembelajaran tahfidz pada sekolah tersebut menggunakan aplikasi pilihan di antaranya dengan Wattsap, Zoom, dan Google Meet. ${ }^{6}$

Dari beberapa penelitian tersebut di atas yang membuat peneliti tertarik untuk meneliti kegiatan program tahfidz yang dilaksanakan di MI Tarbiyatul Athfal saat pandemi ini. Di sekolah tersebut Program tahfidz dilakukan dengan 3 metode yaitu tasmi', tahsin dan murojaah. Karena saat ini, pandemi masih belum belum beranjak pergi, maka kegiatan

\footnotetext{
${ }^{4}$ Widiani Hidayati, Pembelajaran Tahfidzul Quran di Pesantren Pada Masa Pandemi Covid-19, Jurnal Mahasiswa, Khazanah, Vol 12 No. 1 tahun 2020

${ }^{5}$ Rahmat Rifai Lubis dkk, Tahfidz Online (Studi Menghafal Al-Quan di MIS Ubudiyah Medan) Jurnal Pendidikan Islam Vol.09 Nomor 02 tahun 2019

${ }^{6}$ Maria Ulfa, Implementasi Pembelajaran Tahfidzul Quran Pada Masa Pandemi Covid-19 di SMP Quran Darul Fattah Bandar Lampung, Tesis tahun 2021
} 
tahfidz dilakukan dengan Blended Learning yaitu dengan dua strategi, daring dan luring. Penelitian ini diharapkan dapat menambah cakrawala wawasan tentang bagaimana pelaksanaan program tahfidzul Quran saat pandemi ini. Karena kegiatan membumikan AlQuran pada generasi kita tidak bisa dipadamkan dengan hanya sebab pandemi.

\section{METODE}

Pada penelitian ini peneliti menggunakan metode kualitatif deskriptif dengan pendekatan studi kasus. Menurut Creswell Peneltian kualitaf deskriptif merupakan penelitian yang di dalamnya menggunakan pendekatan eksplorasi untuk menelusuri sebuah gejala tertentu. Tentunya dalam penelusuran tersebut dibutuhkan proses wawancara untuk mengumpulkan informasi sebagai data untuk penelitian tersebut ${ }^{7}$. Dengan pendekatan studi kasus yang dipakai peneliti saat ini, akan memfokuskan secara mendalam terhadap gejala atau fenomena tertentu yang didalamnya terdapat sebuah peristiwa, aktifitas, proses, yang dipelajarinya sebagai sebuah kasus ${ }^{8}$.

Data yang digunakan pada penelitian ini yaitu data primer yang dikumpulkan peneliti melalui sumber utama dari lapangan. Dan juga dari data sekunder yang berasal dari data yang sudah berbentuk dokumen. ${ }^{9}$ Dua data tersebut diperoleh melalui tiga cara yaitu wawancara, observasi dan telaah dokumen. Kemudian dianalisis dengan tiga alur kegiatan yaitu dengan reduksi data, display data, dan menarik kesimpulan. Sedangkan teknik keabsahan data dilakukan dengan Triangulasi sumber, waktu, dan teknik ${ }^{10}$.

\section{HASIL PENELITIAN DAN PEMBAHASAN}

\section{Kegiatan Program Thafidzul Quran secara daring (online)}

Setelah pemberlakuan aturan pembatasan social (social distancing ) serta surat edaran menteri pendidikan dan kebudayaan tentang larangan pembelajaran tatap muka. Maka sekolah-sekolah mulai memberlakukan pembelajaran jarak jauh melalui daring. Begitu juga dengan program tahfidz yang dilaksanakan di MI Tarbiyatul Athfal. Pelaksanaannya dilakukan secara online dengan memilih media grup wattasap menggunakan video call. Karena dalam situasi pandemic, kegiatan pembelajaran tidak seharusnya berjalan normal seperti biasanya. Namun siswa harus tetap mendapatkan layanan pendidika secara penuh ${ }^{11}$.

Pemilihan media wattasap dalam setoran tahfidz ini dikarenakan mudah dalam penggunaanya begitu juga aplikasi ini adalah yang paling banyak dimiliki oleh berbagai kalangan baik guru dan siswa sendiri. Sehingga Banyak madrasah atau lembaga tahfidz di

\footnotetext{
${ }^{7}$ Dr. J. R. Raco, M. E, M. Sc, Metode Penelitian Kualitatif, Jenis, Karakteristik dan Keungulannya.(Jakarta, Grasindo,2010) Hal 7

${ }^{8}$ Sugiyono, Metode Penelitian Kualitatif, Kuantitatif, dan R \& D. (Bandung, PT. Alfabet, 2016) hal 17

${ }^{9}$ Iqbal Hasan, Analisis Penelitian Dengan Statistic,( Jakarta, Bumi Aksara, 2004) hal 19

${ }^{10}$ Sugiyono hal 270

11 https://www.tribunnews.com/nasional/2021/02/08/kemenag-terbitkan-kurikulum-darurat-di-masapandemi-covid-19-bagi-jenjang-pendidikan-madrasah
} 
Indonesia yang memakai aplikasi whattsapp dalam kegiatan tahfidz. Dalam aplikasi whatssap ini guru menngunakan fitur grup chat, dimana guru bisa mengumpulkan setiap kontak siswa yang akan dihubungi dengan video call dalam saat pembelajaran ${ }^{12}$.

Alokasi waktu pelaksanaan program tersebut dikurangi yang semula 3 kali dalam seminggu, menjadi 2 kali dalam seminggu. Dengan alokasi waktu tiap pertemuan $2 \times 35$ menit. Begitu juga dengan metodenya yang semula tasmi', tahsin dan murojaah kemudian dipangkas hanya melaksanakan tasmi'.

Metode tasmi' adalah memperdengarkan hafalan kepada orang lain baik perseorangan maupun atau diperdengarkan dihadapan banyak orang. Dalam hal ini siswa akan memperdengarkan hafalan kepada guru. Metode tasmi' sangat efektif karena kekurangan dan kesalahan siswa akan langsung ditegur oleh yang mendengarkan ${ }^{13}$. Dalam penerapannya, metode tasmi' ini banyak dipergunakan dalam program tahfidz. Karena pada metode tasmi' ini terdapat kelebihan diantaranya adalah ${ }^{14}$ :

1. Menjadikan Hafalan Al-quran akan tetap terjaga

2. Dalam proses menghafal akan mempercepat kelancaran

3. Segera mengetahui apabila ada kekeliruan saat membaca ayat-ayat AlQuran

Kegiatan tahfidzul quran dengan metode tasmi' ini melalui tiga tahapan, yaitu pembukaan, kegiatan inti(tasmi') dan penutup.

\section{Kegiatan Pembukaan}

Melalui room chat kegiatan pembukaan tasmi' dilakukan oleh guru pengampu dengan memimpin doa sebelum menghafal Al-Quran dan mengajak siswa berdoa dan bertawassul dari rumah masing-masing. Kemudian mulai menyapa siswa pada anggota grup tersebut dan tetap memotivasi mereka untuk menjaga kesehatan pada masa pandemic, agar tetap bisa menambah hafalan Al-Quran. Kemudian Guru meminta siswa mengisi list kehadiran sebagai absen pada pertemuan tersebut.

\section{Kegiatan Inti}

Pada kegiatan ini, guru mulai melakukan panggilan siswa secara giliran. Dan panggilan akan digilir setiap tatap muka agar mereka semu merasakan urutan panggilan awal, tengah, dan akhir. Setiap sisiwa memiliki buku catatan prestasi hafalan yang akan diisi oleh guru berdasarkan pencapaian setiap kali mereka melakukan talaqqi.

\footnotetext{
12 Jessica Tamara, Strategi Pembelajaran Dosen Melalui Pemanfaatan Media Whatsapp di Masa Pandemi Covid-19 IAIN Curup Bengkulu, jurnal At-Ta'lim Vol.19 No. 02

${ }^{13}$ https://covid19.go.id/storage/app/media/Protokol/2020/Agustus/20200807-pembelajaran-di-masacovid-19-2.pdf diakses tanggal 09 Maret 202110.12

${ }^{14}$ Yuyu wahyudin, Penerapan Metode Tasmi Dalam Pembelajaran Tahsin Tahfidz Untuk Meningkatkan Hafalan Al-Quran: Penelitian quasi eksperimen pada mahasiswa di Rumah Tahfidz Quran UIN Sunan Gunung Djati Bandung, Tesis 2019 hal 45
} 
Aturan saat menyetor hafalan ini dibagi dua. Jika masih mencapai juz 30, maka siswa hanya boleh menyetor hafalan satu surat saja. Sedangkan bagi yang juz 29 dan juz 1 maksimal penyetoran hafalan setengah halaman Al-Quran. Guru akan memberikan catatan kepada setiap siswa dan membubuhkan stiker bintang ketika siswa berhasil menghafal surat dengan lancar dan sesuai tajwid. Jika alokasi waktu habis dan terdapat siswa yang belum menyetor hafalan, guru akan meminta siswa yang bersangkutan untuk menyetor video rekaman hafalan siswa yang bersangkutan.

\section{Kegiatan Penutup}

Pada kegiatan penutup, guru mengevaluasi dari hasil penyetoran hafalan melalui voice chat pada grupp wattasap. Kemudian meminta siswa membaca hamdalah dan doa penutup majlis. Pada pelaksanaan kegiatan tahfidz secara daring ini, pada tahapan evaluasi khusus seperti sambung ayat atau tebak surat tidak terlaksana. Akan tetapi Guru hanya melakukan evaluasi secara umum dari pelaksanaan tahfidz yang telah berlangsung. Hal ini disebabkan oleh terbatasnya alokasi waktu.

\section{Kegiatan Program Thafidzul Quran secara luring (tatap muka)}

Setelah program tahfidz dengan daring berlangsung beberapa pertemuan. Beberapa pihak baik siswa, guru, maupun stake holder merasakan ketidakpuasan. Lebih-lebih para orang tua yang mendapati prestasi putra-putrinya menurun dalam tahfidzul quran. Khususnya dalam bacaan siswa yang masih belum sesuai tajwid dan makhorijul hurufnya. Karena target pencapaian siswa bukan hanya sekedar menghafal melainkan mampu menghafal Al-quran disertai tajwid. Dampaknya anak tidak akan bisa lanjut surat meskipun telah lancar menghafal.

Dalam membaca Al-Quran tentunya tidak lepas dari ilmu tajwid. Jika kita membaca ayat Al-Quran tidak dengan tajwid maka dapat menyebabkan kesalahan arti. Melatih anak-anak agar tepat dalam membaca Al-Quran itu lebih mudah daripada saat dewasa nanti dikarenakan dua hal pertama, karena mereka akan mudah mengingat, dan kedua pada struktur lidah mereka masih elastis (mudah dibentuk) sehingga mudah diarahkan ${ }^{15}$. Dan pelaksanaan hal tersebut kurang efektif jika dilakukan dengan daring.

Oleh karena itu, program tahfidz ini tidak hanya dilaksanakan dengan daring melainkan juga melalui luring. Adapun pelaksanaanya bergantian dengan cara selang seling setiap minggunya. Misalkan minggu pertama tasmi' secara daring maka minggu kedua melaksanakan muroja'ah disertai tahsin secara luring.

Kegiatan Tahfidz secara luring ini dilakukan secara bergilir tiap harinya dengan bergantian antar kelas. Hal ini dilakukan sebagai sikap ikhtiar dari penyebaran covid-19.

${ }^{15}$ https://kumparan.com/nafisatun-nada/pentingnya-belajar-tajwid-sejak-usia-dini 
Karena berdasarkan prinsip kebijakan pendidikan saat pandemic, madrasah harus menjaga hal berikut ini ${ }^{16}$ :

1. Menjaga kesehatan dan keselamatan peserta didik, pendidik, dan tenaga kependidikan, keluarga, dan masyarakat merupakan prioritas utama dalam menetapkan kebijakan pembelajaran

2. Memperhatikan tumbuh kembang peserta didik dan kondisi psikososial juga menjadi pertimbngan dalam pemenuhan layanan pendidikan selama masa masa pandem

Mewujudkan prinsip tersebut di atas, pihak madrasah mewajibkan kepada guru dan siswa untuk tetap mentaati protocol kesehatan setiap kali datang ke sekolah dengan aturan sebagai berikut ;

1. Memakai masker

2. Cuci tangan pakai sabun

3. Pengecekan suhu depan kelas

4. Memakai Hand sanitizer

5. Dilarang bergerombol saat dalam halaqah

Pada kegiatan tahfidul Quran dengan luring ini melaksanakan kegiatan tahsin dan murojaah untuk memperbaiki bacaan siswa yang belum fasih. Metode tahsin digunakan untuk meningkatkan kualitas bacaan Al-quran dengan menitik beratkan pada koreksi kesalahan yang secara umum dilakukan saat membaca Al-quran. Fokus kegiatan tahsin ini pada empat materi yaitu sifatul huruf, makhorijul huruf, dan tajwid. Menurut Abdu Rouf metode ini dilaksanakan dengan musyafahah yautu pembetulan bibir saat membaca saat berhadapan langsung dengan guru atau pembimbing tahfidznya ${ }^{17}$.

Alokasi waktu Pada kegiatan tahsin secara luring ini selama 70 menit untuk kelas rendah (kelas I sampai kelas III), dan 90 menit untuk kelas atas (kelas IV sampai kelas VI) dengan pergantian jadwal masuk sebagai berikut:

Table 1

Jadwal Masuk Kegiatan Tahfidz Secara Luring

\begin{tabular}{|l|c|c|c|}
\hline No & Hari & Kelas & Waktu \\
\hline \multirow{2}{*}{1.} & \multirow{2}{*}{ Senin } & I & $07.30-08.40$ \\
\cline { 3 - 4 } & \multirow{2}{*}{2.} & II & $09.00-10.10$ \\
\cline { 3 - 4 } & \multirow{2}{*}{ Rabu } & III & $07.30-08.40$ \\
\cline { 3 - 4 } & \multirow{2}{*}{ Sabtu } & IV & $09.00-10.30$ \\
\cline { 3 - 4 } & & VI & $07.30-09.00$ \\
\hline
\end{tabular}

Sedangkan pelaksanaanya seperti pembelajarna biasa yaitu terdapat kegiatan pendahuluan, kegiatan inti, dan kegiatan penutup.

\section{Kegiatan pendahuluan}

${ }^{16}$ https://covid19.go.id/storage/app/media/Protokol/2020/Agustus/20200807-pembelajaran-di-masacovid-19-2.pdf

${ }^{17}$ Abdur Rouf, Pedoman Dauroh al-Quran, (Jakarta . Markas Al-Quran, 2014) hal 8 
Dalam setiap halaqah, pertemuan akan diawali salam kemudian membaca doa bersama, yang akan dipimpin guru. Dan dilanjutkan tawassul (membaca Al-Fatihah yang dikhususkan kepada nabi Muhammad, dan pendiri madrasah). Sudah menjadi tradisi di MI Tarbiyatul athfal ketika memulai pembelajaran untuk melakukan tawassul. Sebagai perantara ikhtiyar agar kegiatan tahfidz berjalan lancar, khususnya siswa cepat menghafal dan hafalan tidak mudah hilang.

Setelah itu mengaji bersama. Surat yang dibaca merupakan surat yang ditentukan oleh masing-masing guru, surat yang dibaca tersebut biasanya surat yang tingkat kesulitannya tinggi. Dengan alasan membiasakan siswa membaca Di ruang kelas guru dan santri tetap memakai masker atau face shield

\section{Kegiatan inti}

Setelah mengaji bersama, kemudian guru memanggil siswa secara bergantian. Untuk melasanakan tasmi'. Pelaksanaan tasmi' saat luring ini seperti tradisi pesantren dalam bimbingan membaca kitab atau yang biasa disebut sorogan. Hingga saat ini metode sorogan merupakan metode andalan yang digunakan di pesantren. Definisi sorogan sendiri adalah belajar secara individu dimana peserta didik maju satu persatu untuk berhadapan dengan guru.ada dampak khusus dalam metode sorogan ini, yaitu kebermaknaan dalam metode sorogan terdapat ikatan langsung saat siswa berhadapan dengan guru. Sehingga ikatan emosional bertambah kuat. ${ }^{18}$

Pencatatannya capaian atau prestasi hafalannya tetrap sama. Yaitu guru akan memberikan keterangan di buku catatan siswa. Baik itu yang boleh lanjut surat atau yang harus mengulang, karena bacaan kurang lancarr atau tidak sesuai dengan tajwid dan makhorijul huruf.

\section{Kegiatan penutup}

Sebelum menutup acara kegiatan halaqah, guru akan melakukan tahsin dengan mencontohkan secara langsung bacaan. Guru akan mnencontohkan bacaan yang seringkali terdapat kesalahan saat tasmi'. Dan siswa akan diminta untuk menirukan bacaan yang telah dicontohkan guru.

\section{Kegiatan Evaluasi}

Guru mengevaluasi dengan metode sambung ayat atau tebak surat. Untuk memotivasi siswa, biasanya guru menyediakan beberapa hadiah kecil yang akan diberikan kepada siswa yang benar dalam menjawab. Karena dalam meningkatkan jumlah hafalan, siswa sangat membutuhkan motivasi. Tidak hanya berupa materi, motivasi bisa berupa pujian.

Berdasarkan paparan diatas berikut gambaran perbandingan pelaksanaan kegiatan tahfidz saat pandemic(secara daring dan luring):

Tabel 2

Perbandingan kegiatan tahfidz secara daring dan luring

${ }^{18}$ Armai Arie, Pengantar ilmu dan Metodologi Pendidikan Islam, (Ciputat Press, Jakarta, 2002) hal 150 


\begin{tabular}{|c|c|c|}
\hline $\begin{array}{c}\text { Kegiatan } \\
\text { Tahfidzul Quran }\end{array}$ & Secara Daring & Secara Luring \\
\hline $\begin{array}{l}\text { Kegiatan } \\
\text { pembukaan }\end{array}$ & $\begin{array}{l}\text { - Didahului salam dan } \\
\text { menyapa siswa pada } \\
\text { room chat di grup } \\
\text { whattsap } \\
\text { - Kemudian membaca } \\
\text { doa dan tawassul dari } \\
\text { rumah masing-masing } \\
\text { - Memberikan motivasi } \\
\text { kepada siswa untup } \\
\text { tetrap menjaga } \\
\text { protocol kesehatan }\end{array}$ & $\begin{array}{l}\text { - Didahului salam pada } \\
\text { tiap halaqah } \\
\text { - Dilanjutkan membaca } \\
\text { doa dan tawassul yang } \\
\text { dipimpin oleh guru } \\
\text { - Memotivasi siswa } \\
\text { supaya tetap menjaga } \\
\text { kesehatan dan } \\
\text { menerapkan protocol } \\
\text { kesehatan }\end{array}$ \\
\hline Kegiatan inti & $\begin{array}{l}\text { - Melakukan panggilan } \\
\text { melalui video call } \\
\text { kepada siswa untuk } \\
\text { menyetorkan hafalan } \\
\text { - Jika waktu sudah } \\
\text { sampai, dan masih ada } \\
\text { yang belum } \\
\text { menyetorkan hafalan, } \\
\text { maka siswa diminta } \\
\text { mengirimkan video } \\
\text { saat menghafal. } \\
\text { - Guru memberikan } \\
\text { catatan tentang } \\
\text { capaian hafalan }\end{array}$ & $\begin{array}{l}\text { - Memanggil satu } \\
\text { persatu siswa untuk } \\
\text { tasmi' } \\
\text { - Mencatat capaian } \\
\text { tasmi siswa pada buku } \\
\text { catatan hafalan masing } \\
\text { masing siswa } \\
\text { - Melakukan tahsin } \\
\text { dengan mencontohkan } \\
\text { bacaan dan meminta } \\
\text { siswa menirukannya }\end{array}$ \\
\hline Kegiatan penutup & $\begin{array}{l}\text { - Guru menutup } \\
\text { kegiatan tahfidzul } \\
\text { quran dengan } \\
\text { mengevaluasi secara } \\
\text { umum proses } \\
\text { penyetoran hafalan. } \\
\text { - Guru meiminta siswa } \\
\text { membaca hamdalah } \\
\text { dan membaca doa dari } \\
\text { rumah masing-masing }\end{array}$ & $\begin{array}{l}\text { - Guru mengevaluasi } \\
\text { proses pelaksanaan } \\
\text { tasmi dengan } \\
\text { memberikan } \\
\text { pertanyaan berbentuk } \\
\text { sambung ayat atau } \\
\text { tebak surat } \\
\text { - Guru bersama siswa } \\
\text { membaca hamdalah } \\
\text { sebagai penutup } \\
\text { kegiatan tahfidz. }\end{array}$ \\
\hline
\end{tabular}


Hasil-hasil yang diperoleh dari perbandingan pelaksanaan tahfidz antara daring dan luring, terdapat kelebihan dan kekurangan pada keduanya. Pada dasarnya keduanya memiliki aspek berbeda namun untuk tujuan yang sama. Berikut adalah gambaran kelebihan dan kekurang pelaksanaan kegiatan tahfidz secara daring dan luring yang dilaksanakan di MI Tarbiyatul Athfal.

Tabel 3

Kelebihan dan Kekurangan

\begin{tabular}{|c|c|c|c|}
\hline No & $\begin{array}{c}\text { Kegiatan } \\
\text { Tahfidz }\end{array}$ & Kelebihan & Kekurangan \\
\hline 1. & Daring & $\begin{array}{l}\text { - Siswa tidak } \\
\text { tegang saat } \\
\text { menghafal } \\
\text { karena tidak } \\
\text { berhadapan } \\
\text { langsung dengan } \\
\text { guru }\end{array}$ & $\begin{array}{l}\text { - } \text { tidak semua siswa } \\
\text { memiliki fasilitas } \\
\text { paket data yang } \\
\text { memadai } \\
\text { - tidak semua siswa } \\
\text { tinggal di kawasan } \\
\text { jaringan internet yang } \\
\text { bagus siswa } \\
\text { - semangat menghfal } \\
\text { dalam } \\
\text { menurun } \\
\text { - tidak ada proses } \\
\text { evaluasi khusus }\end{array}$ \\
\hline 2. & Luring & $\begin{array}{l}\text { - kegiatan tahfidz } \\
\text { berjalan efektif } \\
\text { dan siswa sangat } \\
\text { antusias } \\
\text { - mudah dalam } \\
\text { pelaksanaan } \\
\text { tahsin } \\
\text { - mudah dalam } \\
\text { mengevaluasi } \\
\text { kegiatan tahfidz }\end{array}$ & $\begin{array}{l}\text { - pengawasan saat } \\
\text { pandemic bagi siswa } \\
\text { yang tidak patuh } \\
\text { terhadap protocol } \\
\text { kesehatan }\end{array}$ \\
\hline
\end{tabular}

Berdasarkan penjelasan dari Kepala Madrasah dan para guru pengampu program tahfidz bahwa dilakukannya kegiatan tahfidz secara blended learning dikarenakan pencapaian yang kurang maksimal saat kegiatan tahfidz dilakukan hanya melalui daring via whatsap. Kelemahan yang dirasakan para guru dan siswa di antaranya adalah pencapaian dari hafalan siswa dari segi tajwid dan makhorijul huruf yang kurang bagus sehingga akan memakan waktu yang lama dalam menuntaskan satu surat. Hal tersebut diakibatkan oleh bervariasinya keadaan dari kekuatan jaringan internet yang mendukung 
penggunaan video call dalam whatsaap. Jika kekuatan sinyal buruk maka menyebabkan penjelasan guru akan terputus-putus serta pemberian contoh bacaan tidak terdengar jelas.

Dengan diterapkannya strategi blended learning, bisa menutupi kekurangan yang dirasakan saat pelaksanaan secara daring. Seperti pemantapan tajwid dan makhorijul huruf yang dilakukan dalam bentuk muroja'ah dan tahsin. Sebagaimana visi misi yang disampaikan Kepala Madrasah bahwa, hafalan siswa tidak hanya terpacu dalam kuantitas melainkan kualitas. Hal ini terbukti dengan adanya aturan bahwa siswa tidak bisa lanjut surat meski lancar bacaannya dikarenakan bacaan yang kurang bagus dalam segi tajwid dan makhorijul huruf.

\section{KESIMPULAN}

Berdasarkan pemaparan di atas, dapat disimpulkan bahwa Pelaksanaan kegiatan tahfidz di MI Tarbiyatul Athfal pada masa pandemi dikakukan dengan dua cara. Pertama secara daring. Pada pelaksanaan secara daring mulai dilaksanakan sejak pemerintah menghimbau untuk melakukan pembelajaran jarak jauh. Dengan menggunakan aplikasi whatssap, kegiatan tahfidz hanya fokus pada tasmi' melalui video call dengan alokasi waktu 70 menit. Namun karena terdapat banyak kekurangan dalam pelaksanaannya, maka dilaksnakan juga secara luring. Capaian hafalan siswa akan dicatat dalam buku catatan siswa dengan memberi stiker bintang bagi siswa yang lanjut surat. Kedua, secara luring. Pelaksanaan kegiatan tahfidz secara luring dilaksanakan di sekolah dengan tetap mengikuti aturan protocol kesehatan. Dalam satu hari hanya dilaksanakan dua kelas dan jam masuk pada setiap harinya dijadwalkan bergantian dengan kelas berikutnya. Metode yang dipakai saat luring tidak hanya tasmi' tapi juga tahsin disertai murojaah.

\section{DAFTAR PUSTAKA}

Arie, Armai. 2002. Pengantar ilmu dan Metodologi Pendidikan Islam, Jakarta: Ciputat Press

Aziz, Abdul. 2004. Kiat Sukses Menjadi Hafidz Quran Da’iyah, Bandung:PT Syamil Cipta Media

Hasan, Iqbal. 2016. Analisis Penelitian Dengan Statistic. Jakarta:Bumi Aksara

Rahmat Rifai Lubis dkk, 2019. Tahfidz Online (Studi Menghafal Al-Quan di MIS Ubudiyah Medan) Jurnal Pendidikan Islam Vol.09 Nomor 02

Raco, D R. 2010. Metode Penelitian Kualitatif, Jenis, Karakteristik dan Keungulannya. Jakarta: Grasindo

Rouf, Abdur. 2014. Pedoman Dauroh al-Quran. Jakarta: Markas Al-Quran

Sugiyono, 2016. Metode Penelitian Kualitatif, Kuantitatif, dan $R \& D$. Bandung: PT. Alfabet

Tamara, Jessica Strategi Pembelajaran Dosen Melalui Pemanfaatan Media Whatsapp di Masa Pandemi Covid-19 IAIN Curup Bengkulu, jurnal At-Ta'lim Vol.19 No. 02 
Yunus, Mahmud. 2013. Kamus Arab Indonesia. Jakarta: Mahmud Yunus Dzurriyah

Wahyudin, Yuyu Penerapan Metode Tasmi Dalam Pembelajaran Tahsin Tahfidz Untuk Meningkatkan Hafalan Al-Quran: Penelitian quasi eksperimen pada mahasiswa di Rumah Tahfidz Quran UIN Sunan Gunung Djati Bandung, Tesis 2019

https://kumparan.com/nafisatun-nada/pentingnya-belajar-tajwid-sejak-usia-dini https://covid19.go.id/storage/app/media/Protoko1/2020/Agustus/20200807-pembelajarandi-masa-covid-19-2.pdf

https://www.tribunnews.com/nasional/2021/02/08/kemenag-terbitkan-kurikulum-daruratdi-masa-pandemi-covid-19-bagi-jenjang-pendidikan-madrasah

https://www.kompas.com/sains/read/2020/05/11/130600623/diumumkan-awal-maret-ahli-virus-corona-masuk-indonesia-dari-januari 